\title{
O infamiliar [Das Unheimliche] - Uma edição crítica à sua maneira
}

\section{O infamiliar [Das Unheimliche] - A critical edition on its own way}

\author{
Jean Dyêgo Gomes Soares ${ }^{1}$
}

Resumo: Resenha de Freud, S. (2019). O infamiliar / Das Unheimliche, seguido de O Homem da Areia. Trad. Ernani Chaves, Pedro Heliodoro Tavares e Romero Freitas. Belo Horizonte: Autêntica.

Palavras-chave: Intraduzível; Estranho; Infamiliar; Inquietante.

Abstract: Review of Freud, S. (2019). O infamiliar / Das Unheimliche, followed by $O$ homem da areia. Translated by Ernani Chaves, Pedro Heliodoro Tavares and Romero de Freitas. Belo Horizonte: Autêntica.

Keywords: Untranslatable; Strange; Unfamiliar; Unsettling.

Os estudiosos de Freud soam unânimes quando o assunto é um texto seminal de 1919, Das Unheimliche: concordam ser um texto desconcertante (Saliba, 2004; Martini et al, 2010; Iannini e Tavares, 2019, Rabelo et al 2019). Numa encruzilhada no interior da obra do alemão, entre os textos de disseminação da psicanálise e os de metapsiocologia, esse pequeno opúsculo em torno de um termo, se debruça também em detalhe sobre $O$ Homem da Areia, de E. T. A. Hoffmann, e ocupa posição relevante para compreender livros posteriores como Além do princípio do prazer. Com um estilo atipicamente truncado, o texto tem, porém, outro famoso motivo de desconcerto: a tradução do termo que lhe dá título. A listagem pode parecer algo elaborado por Jorge Luís Borges, mas não é nada ficcional: em francês L'inquiétante étrangeté(Gallimard), L'inquiétant familier (Payot), L'inquietant (PUF); em espanhol, Lo siniestro (Biblioteca Nueva) ou Lo ominoso (Amorrortu); em italiano, Il perturbante (Boringhieri); em inglês The uncanny (Standard Edition); em português, $O$ estranho (Edição Standard) ou $O$ inquietante (Companhia das Letras), e agora $O$ infamiliar na tradução de Ernani Chaves e Pedro Heliodoro Tavares Todos parecem querer dar conta de uma palavra com sentido antitético como bem lembram os editores (Iannini e Tavares, 2018, p. 8).

\footnotetext{
1 Trabalha com História da Filosofia. Leciona atualmente na Universidade Federal de Lavras (UFLA). É Doutor e Mestre em Filosofia pela Pontifícia Universidade Católica do Rio de Janeiro, e se graduou na mesma área pela Universidade Federal de Ouro Preto. Sua atuação tem ênfase em filosofia da linguagem, da ficção e literatura, em retórica e estética. Interessa-se por filosofia da ciência e ética. Desenvolve projetos em filosofia da educação e práticas de convivência.
} 
Diante de tantas alternativas, a presente edição comemorativa lançada pela editora Autêntica com a contribuição de um time vigoroso de especialistas em torno do tema, toma uma decisão acertada, a saber, mais do que traduzir um texto desconcertante, discutir suas possibilidades. A escolha de um neologismo - "infamiliar" - transmite ao leitor uma inevitável responsabilidade semântica de também participar da construção de um novo sentido, mas compensa isso com uma fluidez inédita em português para a assimilação do caráter antitético do termo alemão. São escolhas inerentes ao processo de tradução e, como lembram os editores, estamos diante do que Barbara Cassin chamou "intraduzível”: “[...] o intraduzível não é o que não pode ser traduzido, mas o que não cessa de (não) traduzir" (Cassin apud Iannini e Tavares, 2019, p. 8). Como um contributo no meio da babélica cena de tradução desse texto freudiano, um novo signo procura seu espaço.

Ao que nos parece, com o passar do tempo, essa alternativa pode se firmar. Isso não só pelo aspecto morfológico acertado, já que infamiliar é morfologicamente semelhante a Unheimliche cujo radical alemão heim- remete ao que é familiar; há de se considerar também que o adjetivo "familiar" em português possui um sentido antitético, isto é, pode tanto falar de coisas que conhecemos bem, quanto daquelas que dão a impressão de serem conhecidas e, no entanto, podem não o ser. Quando dizemos que fulano é familiar, sugerimos que reconhecemos algo naquela pessoa, mas ela permanece estranha, isto é, infamiliar para nós. Esse aspecto é central para a primeira parte da argumentação freudiana que, se debruçando sobre os sentidos dicionarizados do termo, apela para o aspecto antitético para aproximar o Heimliche de seu antagonista, o Unheimliche. Nas palavras do autor: "[...] familiar [Heimlich] é uma palavra cujo significado se desenvolveu segundo uma ambivalência, até se fundir, enfim, com seu oposto, o infamiliar [Unheimlich]. Infamiliar é de certa forma um tipo de familiar" (Freud, 2018, p. 47-9, grifos do autor). O exercício de elaborar traduções alternativas, feito à exaustão por Ernani Chaves e Pedro Heliodoro Tavares, torna clara a dificuldade de outras traduções em apresentar esse caráter antitético. Seria o caso de sugerir como tradução que "o estranho é de certa forma um tipo de conhecido"? Que "o inquietante é de certa forma um tipo de "quietude"? Em nenhuma dessas alternativas, os sentidos antitéticos presentes no par heimlich-unheimlich, algo elementar para a economia argumentativa de Freud, está presente. Enquanto era nublado pela língua no interior de alternativas como essas, o caráter antitético é claramente ressaltado nesta nova edição. 
Além disso, o volume celebra os cem anos de publicação do texto de Freud, ligando-o em português a seu objeto de estudo com a tradução inédita do conto de E.T.A. Hoffmann, $O$ Homem da Areia. O conto e sua análise por Freud mostram novos caminhos para a estética, agora não mais restrita só à doutrina do belo, mas “[...] como a doutrina das qualidades do nosso sentir" (Freud, 2019, p. 29), ainda que seja algo infamiliar diante dos duplos que surgem na literatura de Hoffmann. O tradutor do conto Romero Freitas, germanista que sugeriu o neologismo infamiliar, assina ainda um sintético e poderoso posfácio em que situa o lugar de Hoffmann na literatura e no pensamento alemão de seu tempo.

Não obstante isso, os editores, a fim de facilitar a consulta do leitor, recuperam dois ensaios importantes já publicados em outro momento da mesma coleção Obras Incompletas de Sigmund Freud, a saber, O sentido antitético das palavras e A negação. Ambos artigos salientam a centralidade de $O$ infamiliar para o pensamento de Freud e estimulam uma primeira conexão entre seu estranho texto e o restante da obra.

Ainda sobre o volume, este convoca vozes nacionais de projeção a ensaiar em torno da monografia de Freud. O ensaio de Ernani Chaves apresenta as nuances de "algo que parece plano" com sinceridade e profundidade loquazes, conectando o texto de 1919 a nossa atualidade teórica, histórica e arquitetônica. Guilherme Massara e Gilson Iannini aprofundam possibilidades estéticas abertas por um texto de um Freud ousado, que pouco pede indulgência ao postular ideias "mais além do sublime". Christian Dunker pensa $O$ infamiliar como encruzilhada entre três caminhos, ensaiando ainda conexões arrojadas, como a da ligação do pensamento de Freud com a antropologia de Eduardo Viveiros de Castro.

O todo do livro apresenta a tese da centralidade de Das Unhemiliche para o pensamento estético de Freud, mas permite extrapolar qualquer pretensão de extemporaneidade na direção de nosso presente: afinal, há algo de familiar nos infamiliares que nos assolam e algo de infamiliar em alguns encontros com o familiar. De alguma forma, não são completamente estranhos, e apesar de terríveis, os falsos mitos somam discursos bárbaros nos jornais. Discursos que se parecem com os duplos de nossa história. Assim, indiretamente, esse volume propõe uma maneira diferente de fazer uma edição crítica - provoca diálogos, desperta interesses, amplifica possibilidades, ao invés de somente glosar em notas de rodapé, linha por linha, os sentidos possíveis do que seria o infamiliar nesses tempos de terra em transe. 


\section{Referências}

Freud, S. (2019). O infamiliar / Das Unheimliche, seguido de O Homem da Areia. Trad. Ernani Chaves, Pedro H. Tavares e Romero Freitas. Belo Horizonte: Autêntica.

Iannini, G; Tavares, P. H. (2019). "Freud e o infamiliar". In: FREUD, S. O infamiliar / Das Unheimliche, seguido de O Homem da Areia. Trad. Ernani Chaves, Pedro H. Tavares e Romero Freitas. Belo Horizonte: Autêntica.

Martini, A; Coelho JR., N. E. (2010). "Novas notas sobre 'O Estranho"”. In: Tempo psicanalítico, Rio de Janeiro, v.42.2, p. 371-402.

Rabelo, F. Martins, K. Sträter, T. (2019). “As referências literárias em 'Das Unheimliche"”. In: Rev. latinoamericana de psicopatologia fundamental. vol. 22, n .3, São Paulo

Roudinesco, E; Plon, M. (1998). Dicionário de psicanálise. Rio de Janeiro: Zahar.

Saliba, A. M. P. (2004). "O vidro da palavra: o estranho como objeto-limite entre literatura e psicanálise. In: Revista Em tese, Belo Horizonte, v. 8, p. 29-36. 